\title{
Reckoning: The 1991 Siege of Dubrovnik and the Consequences of the "War for Peace"1
}

The 1991 siege of the Croatian coastal city of Dubrovnik, which lasted nine months and had devastating consequences for the city and the entire region, at the time re-focused the world's attention on the war in the former Yugoslavia. The events surrounding the earlier destruction of Vukovar by the Yugoslav People's Army (JNA) and various Serbian paramilitary groups, coupled with the long-lasting and seemingly absurd attack on Dubrovnik, helped redefine the perception of the conflict in the former Yugoslavia. ${ }^{2}$

The varied assessments of the military operations in the region of Dubrovnik still provoke lengthy and passionate debates among historians and politicians, leaving many questions unanswered, while ordinary Montenegrins and Serbs are left to their own devices to cope with their feelings of uneasiness about the recent past. They struggle with questions such as who initiated the process and who is to blame for its catastrophic results? Was there a siege at all, or was the JNA advancing into Croatia in order to liberate its citizens from the "oppressive Ustasha regime" as it was claimed at the time by some of the more radical politicians in Serbia and in Montenegro? Whose soldiers besieged the city, Serbian or Montenegrin? Was there a shelling of Dubrovnik or was it all staged by local pyrotechnicians in order to mislead the international community into believing that the city fell victim to the Greater Serbian military invasion ${ }^{3}$ 
Answers to these questions vary depending on whom you ask, how you pose a question, and why you ask it. In other words, answers are informed by differences in understanding the reasons behind the dissolution of the former Yugoslavia and by different views of the internal dynamics of this process, all of which are shaped by strong emotional attachments to particular national paradigms. Even though in the case of the siege of Dubrovnik the available evidence provides answers to some of the questions posed, I am also conscious of the fact that this article is part of an ongoing debate on the causes of the dissolution of the former Yugoslavia. Therefore, the aim of this text is to present my own assessment of a specific episode of the Yugoslav conflict, while recognizing that my analysis may be in opposition to the predominant discourse. Discussing the siege of Dubrovnik and debating a number of issues is, I believe, the right point of departure in the process of facing the past and dealing with the consequences of earlier mistakes.

This article will elaborate on the dynamics of the siege of Dubrovnik and analyze its political background and its implications. It will discuss the role Montenegrin political and military elites played in this conflict. My intention is to provide the necessary historical context for a better understanding of these events, as well as to problematize numerous discourses that have been applied in attempts to resolve the issue. I believe that the subject is much too important to remain hidden in the labyrinth of contemporary political bartering between Montenegro, Croatia, and the international community. I am also acutely aware of the fact that this essay is just a sketch of a much broader subject that begs further research.

The following text is, in most part, based on evidence provided by numerous international organizations such as the UNESCO, various UN commissions of experts, and the EU Observer's reports, as well as the International Criminal Tribunal for the former Yugoslavia in The Hague (ICTY). I have also examined secondary sources on the war in Croatia, both in English and Serbo-Croat, and also scrutinized numerous media reports of the period and critically evaluated their content. With regards to primary sources in Serbo-Croat, I would like to point out the scarcity of official documents related to political decision-making and military operations during the Dubrovnik campaign. This article also carries a mark of personal experience, since I lived in Montenegro at the time and followed the events on the ground very closely. The bulk of the research for this article was completed during months of preparation of the textual version of the historical account of the siege for the upcoming "OBALA" produced three-part TV documentary entitled "The War for Peace." 4 
HISTORY, POLITICS, AND THE BACKGROUND OF THE

"With God's help, this time next year Dubrovnik will be the capital of Montenegro, and the Summer Games will be held in Niksic." 5

Dubrovnik was founded in the mid-seventh century. For a long time it was under the protection of the Byzantine Empire, whose armies broke the fifteen-month long siege of Dubrovnik by the Saracens in 887. Some hundred years later, in 992, the Byzantine rulers acted again in support of Dubrovnik, after the city was burned down by the Bulgars. In the year 1000, Dubrovnik recognized the authority of Venice, but in 1018 returned under the protective wing of the Byzantine Empire. In 1185 the Serb ruler Stefan Nemanja attempted to conquer Dubrovnik but without success. As the result of the peace treaty signed with Stefan Nemanja, Dubrovnik was granted the right to trade with the province of Raska (Ras). From 1205 to 1358 the city was again under Venetian sovereignty, but after the signing of the Peace Treaty of Zadar in 1385, it became part of the HungarianCroatian Kingdom. Throughout the centuries and in spite of (or because of) foreign patronage, this city managed to preserve its independence. ${ }^{6}$ During the late fourteenth and early fifteenth centuries Dubrovnik was a flourishing city-state with diplomatic representatives in Madrid and Rome. Dubrovnik especially prospered from the fifteenth to the eighteenth centuries and was Venice's chief rival. In the sixteenth century Dubrovnik had a fleet of 200 large ships, which grew to 300 in the eighteenth century. Around 1780, ships from Dubrovnik sailed to New York and Baltimore. Throughout its history this city was the port of call on the Adriatic coast for merchants and politicians, as well as travelers, artists and tourists alike. Its rich cultural heritage attracted the attention of many. ${ }^{7}$ In 1806, the French army occupied the city and two years later Marshal Marmont abolished the Dubrovnik Republic and placed it under French rule. Following the 1815 Congress of Vienna, the city was annexed by Austria and remained part of the Austro-Hungarian Empire until the conclusion of the First World War. From 1918 to 1939 Dubrovnik was part of the Zetska Banovina (District) and from 1945 to 1990 of the Socialist Federal Republic of Yugoslavia. ${ }^{8}$ With its many medieval churches, cathedrals, and palaces from the Baroque period, the Croatian city of Dubrovnik (in 
medieval times called Ragusa) is indeed the pearl of the Adriatic, and in 1974 it was listed by UNESCO as a world heritage site. ${ }^{9}$

The Old Town is contained in a small area. This dense urban space is confined by fortifications dating mainly from the fifteenth and sixteenth centuries. The municipal regulation of 1272 dictated building standards and forms that were long respected. This regulation also softened the impact of changing architectural styles in the Mediterranean world. The reconstruction that followed the catastrophic earthquake of $1667 \mathrm{did}$ not radically change the architectural character of the city. Dubrovnik engaged Italian architects, whose creations (even those of the Baroque period such as St. Blaise Cathedral and, to a lesser extent, the Jesuit church) would not clash excessively with the surrounding architecture. Igor Zidic rightly pointed out that in Dubrovnik, "it is not size that produces an illusion of order but rather order that produces an impression of size."10 The Old Town is not only an architectural and urban ensemble of high quality, but it is also full of museums and libraries, such as the collection of the Ragusan masters in the Dominican Monastery, the Museum of the History of Dubrovnik, the Icon Museum, the libraries of the Franciscan and Dominican Monasteries, to mention but the most famous. Above all, it houses the archives of Ragusa. Kept continuously since the last quarter of the $13^{\text {th }}$ century, these archives are "the most important source for Mediterranean history" according to the French historian, Fernand Braudel. ${ }^{11}$

In 1991, Dubrovnik was the center of a region encompassing approximately 979 square kilometers, stretching from the Prevlaka Peninsula (bordering Montenegro) to the Peljesac Peninsula. According to the 1991 census, over 71,000 people lived in the region of Dubrovnik, 50,000 of whom lived in the city itself: 82.4 percent were Croats, 6.8 percent were Serbs, and 4 percent were Muslims. ${ }^{12}$ The rest of the population was of mixed ethnic background due to mixed marriages and displayed elements typical for almost 20 different ethnic groups.

As the former Yugoslavia fell apart during the early 1990s, with Slovenia, Croatia, and Bosnia seeking independence, Dubrovnik captured the world's attention once again. This time, however, this coastal city did not appear on the covers of newspapers around the globe on account of the splendor of its palaces or the opulence of its cultural artifacts. It was because Dubrovnik was under siege and artillery shells were falling onto the city.

In early 1991, following the upswing of Greater Serbian nationalism epitomized by the policies of Slobodan Milosevic, other nationalist- 
minded elites in the former Yugoslav republics of Slovenia, Croatia, and Bosnia opted for secession and sought independence, thus disturbing the fragile ethnic balance in the region and creating areas populated by the "unwanted other."13 On June 25, 1991, Croatia seceded from the Socialist Federal Republic of Yugoslavia (SFRY) and declared independence on October 8, 1991. What followed were years of bitter fighting for ideologies and territories between Serb and Montenegrin volunteers and paramilitaries coordinated and supplied by the Serb-controlled JNA on the one hand, and Slovene, Croat, and Muslim forces on the other.

The legal aspects of the Dubrovnik campaign and the war in Croatia in general are still a matter of contention. Some Serbian and Montenegrin legal experts argue that the conflict was a civil war and an internal Yugoslav matter. It could also be argued that the Dubrovnik Campaign was an international conflict, considering that Croatia became an independent state on October 8, 1991, only eight days after JNA soldiers entered its territory. International recognition of Croatian independence indeed came much later, and this delay is often used as proof of the internal nature of the conflict around Dubrovnik. The legal finessing does not, however, diminish the fact that by the time of the JNA's advance towards Dubrovnik, Croatia was not a constitutive element of the SFRY in any meaningful way. Those who favor arguments along the lines of the so-called unconstitutional secession of Croatia should note that the Socialist Federal Republic of Yugoslavia, whose preservation was claimed to be the main reason for the armed conflict in Croatia, had already ceased to exist as a unified country, and its constitution was made null and void during the June 30, 1991 closed session of the Council for the Defense of the Constitution, when the Serbian representative, Borislav Jovic, announced that Serbia was in favor of Slovene secession. ${ }^{14}$ Furthermore, the Federal Defense Secretary at the time, General Veljko Kadijevic, acknowledged that once the decision to let Slovenia go was reached, the JNA "would have to fight for the borders of a new Yugoslavia composed of those peoples who wanted to live together in it and who would not allow the disintegration of Yugoslavia as such."15

In July and August of 1991, the military situation in Croatia worsened due to numerous attacks organized by various Serbian paramilitary forces supported by the JNA. On August 1, 1991, a coalition government was formed in Croatia under the presidency of Franjo Tudjman, and two weeks later the JNA intervened in Eastern Slavonia, with a massive attack on the Croatian town of Vukovar beginning on August 26. Further operations were carried out by the JNA in the Krajina region and along 
the Dalmatian coast, where Croatian towns were blockaded from the sea. On September 25, 1991, the United Nations introduced an arms embargo on all the republics of the former Yugoslavia. ${ }^{16}$ At that time, the Yugoslav navy blockaded the southern coast of Dubrovnik, and the JNA deployed its forces along the border with Croatia. On September 23, 1991, the Croatian villages of Vitaljina, Brgat, and many others were subjected to intensive artillery shelling.

With the generous assistance of the state-controlled media, Montenegrin officials argued that the country faced an immanent threat and used every opportunity to point out that Montenegro would defend itself by any means available. With regards to the military situation in Croatia and the former Yugoslavia in general, the government-controlled Montenegrin daily Pobjeda played a crucial role in "reminding" the citizens of Montenegro of the traditional notions of justice, honor, duty, historical right, and the "urgency" of defending the motherland against the forces of fascism and oppression. Any display of pacifism was interpreted as treason and an act of cowardice. The self-proclaimed leader of the SKPokret za Jugoslaviju (League of Communists - Movement for Yugoslavia) R. Krsmanovic, argued that "to be a pacifist at this time comes very close to surrendering to fascism in much the samemanner as in 1941."17 A month later, Krsmanovic's views were reinforced by then Prime Minister Milo Djukanovic. In an interview with Pobjeda, the Montenegrin prime minister proclaimed that an attempt to promote the principle of voluntary service in the army was a big mistake because "when the motherland is in danger such a principle does not apply."18 Djukanovic further stated that it is "patriots who are fighting because their state is put in jeopardy," while he acknowledged opposition to the war as "some sort of abstract pacifism in the public sphere." 19 He also threatened all those reluctant to serve on the "threshold of homeland" with a special law that should be put in effect. This new law, according to Djukanovic, should introduce much harsher punishment for deserters, instead of simply "firing them from their jobs." 20 Furthermore, the Montenegrin prime minister remarked that because of the Croatian chequered flag he would never again play chess. ${ }^{21}$

Pobjeda's 1991 editorials tried to explain the Yugoslav crisis in simple binary terms: the conflict between diplomacy and arms, which started in 1991. "Croatia and Slovenia chose arms as the means for achieving their political goals. Under the veil of 'the democratic process' they secretly armed themselves, which clearly showed that the 'young Croatian democracy' was based on primitive nationalism and feudal, Jelacic-like stable boy attitude." 22 Such an approach to the Yugoslav crisis was 
further elaborated on by leading Montenegrin politicians at the time. The deputy leader of the ruling DPS, Svetozar Marovic, saw the causes of the Yugoslav demise in "the continuity of an aggressive imperialist Catholicism, which viewed Yugoslavia as a marginal element and an episode in the process of acquiring larger realms of domination," while "the current Croatian leadership, with its neo-fascism, its tendencies towards global militarization and its attempt to disguise genocide, represents one of the greatest dangers not only for the Yugoslav peoples but it is also a danger for Europe." 23 In his weekly column, Marovic also elaborated on the nature of Croatian history and its fundamental "flaws" commenting that it had to "re-invent itself in the heads of its militant nationalists since the bases for the Croatian state law are grand illusions and non-existent facts." 24 According to Marovic, the main stay of Croatian national politics was and continues to be "the demand for the destruction of Serbs in the areas of the so-called historical territories," and such actions were to be carried out by "the force of arms and by slaughtering of the innocent." 25

During the early fall of 1991 the political leaders of Montenegro and the military brass of the JNA rationalized the aggression on Dubrovnik as a necessary move towards protecting the territorial integrity of Montenegro and Yugoslavia and preventing a potential conflict along ethnic lines, as well as stopping the so-called unconstitutional secession of Croatia. Montenegrin Prime Minister Djukanovic raised the hopes of many nationalists in Montenegro when he stated that the "Croatian authorities wanted to have a war and they will have it." ${ }^{26} \mathrm{He}$ continued by saying that "if Croatia wants to secede then the internal borders must be revised," while interpreting the war in Croatia as an inevitable outcome of the totalitarian policies of Zagreb: "One million Serbs in Croatia are deprived of their right and are forced to respond with arms."27 He assured the people of Montenegro that the time had come to "draw the demarcation lines vis-à-vis the Croats once and for all," and that "the new borders with Croatia would be more logical and just than those drawn by the old and poorly educated Bolshevik cartographers." 28

MILITARY AND POLITICAL DYNAMICS OF THE SIEGE

On September 16, 1991, the JNA issued a call for mobilization in Montenegro. The Command of the Titograd Corp ordered all conscripts and all those who were to provide material support and supplies in 
livestock and were listed as members of War Unit No. 2277 to immediately proceed to a pre-designated location. The order stated: "Due to a sudden worsening of the overall political and security situation in the whole country, and in Croatia in particular, where the broader escalation occurred, the mobilization of War Unit No. 6247 in the Military Naval Sector Boka is also ordered." 29 The following day, the commander of the Titograd Corp addressed conscripts via Radio Niksic and explained the reasons behind this mobilization. Two days later, Pobjeda reported on this radio address and quoted the army commander's justification for this action under a somewhat cynical title, "Mobilization for Defense." According to Pobjeda, the Commander of the Titograd Corp appealed to every citizen of Montenegro "to fulfill their constitutional obligation and right to defend freedom, independence and territorial integrity, and defend the country whose foundations are threatened."30

It would seem that mobilization was not proceeding smoothly in spite of the brave face the authorities were trying to put on. Frequent criticism of deserters and pacifists in the media indicate that a considerable number of Montenegrins were reluctant to don a uniform and fight for an imaginary category such as the undying spirit of Serbhood. In order to further "motivate" the conscripts to join the fight for the preservation of their motherland, the Montenegrin People's Party (closely allied with Slobodan Milosevic's Socialist Party of Serbia) called on its members to join the JNA. The leadership of the People's Party reminded Montenegrins of all the "ills" caused by the former communist regime in Yugoslavia and appealed to their feelings of pride and of belonging to the larger Serbian family. Following the rhetoric of Greater Serbian expansionist nationalism, this proclamation referred to the need for defending "the Serbian territories within and outside the Montenegrin borders." 31 It also reminded the party faithful that "Montenegro's glorious past determines the actions of Montenegrin patriots of today: coordinating interests of the Montenegrin people with the general interests of Serbdom," while it characterized calls for the demilitarization of Montenegro as "calls for treason, hoped for by the HDZ likeminded people in Montenegro, and Kosovo and Metohija." 32

The general public in Montenegro was further informed about the "dangerous silence" on the border with Croatia in an article entitled "The Guns are Silent," by M. Vico, Pobjeda's reporter on the ground. ${ }^{33}$ While confirming that there were no new developments on the Montenegrin border with Croatia and in the vicinity of the army barracks on Prevlaka Peninsula, Vico wrote about a tense standoff between the two sides. He 
emphasized that the morale among the JNA troops was high and warned that if the Croatian "'guards' and 'police' dare to attack they will indeed regret it." 34 Two days later, he reported on the first exchange of fire and placed the blame for this incident squarely on the Croatian side. The Croatian forces allegedly fired from their camp in the village of Vitaljina. Judging by this report the JNA reservists responded with small arms fire, which according to Vico, was sufficient to "scare and silence the 'guards' on the other side." 35 It is interesting to note that until September 27 the government controlled media in Montenegro regularly used the phrase "border between Montenegro and Croatia." From that point on, the language changed, and a new phrase was adopted: "the administrative border between Montenegro and Croatia." The adjective "administrative" served the purpose of characterizing the border as a matter of form rather than substance. By not referring to it (or perceiving it) as a border between two states, the Montenegrin political leadership and the army brass were able to present to the outside world the subsequent JNA's invasion of Croatia as an internal conflict and not as an international one. 36

In the wee hours of the morning of October 1, 1991, shortly after the JNA commander of the Military Naval Sector Boka, Admiral Krsto Djurovic, died under somewhat suspicious circumstances, JNA soldiers and reservists initiated military operations in the region of Konavle and around the Croatian coastal city of Dubrovnik. ${ }^{37}$ Just after 5:00 a.m. the people living in the Croatian village of Vitaljina and throughout the region of Konavle were awaken by heavy artillery fire coming from the JNA positions at Prevlaka Peninsula, Prijevor, Mojdez, and also from the JNA's naval vessels anchored off the Croatian coast. ${ }^{38}$ The artillery fire was followed by an infantry thrust into Croatian territory. The bulk of these forces consisted of army reservists from Montenegro, whose crossing onto the Croatian territory was backed by planes, armor and artillery of the JNA.

The JNA entered the region by several routes and began to move steadily northwest through Konavle toward the city of Dubrovnik. This action was coordinated with a similar, multiple-axis advance toward Dubrovnik through Primorje and the area known as Rijeka Dubrovacka (northwest of Dubrovnik). The JNA unit which later occupied the hills above Dubrovnik was the Third Battalion of the JNA 472 (Trebinje) Motorized Brigade, under the command of Captain First Class Vladimir Kovacevic - Rambo. For the purposes of the Dubrovnik campaign this battalion was attached to Military Naval Sector Boka with headquarters 
in Herceg Novi, and was put under the overall command of the Vice Admiral Miodrag Jokic. The Third Battalion consisted of three sharpshooter (rifle) companies, one anti-tank company, one mixed-mortar company, and one tank detachment. It had the strength of approximately 800 to 1000 personnel, with 50 per cent being professional JNA soldiers, while the rest were reservists from Montenegro and Bosnia-Herzegovina. The other formations and units of the JNA, including the above-mentioned unit, as well as the forces of Naval Sector Boka that were involved in the Dubrovnik campaign were subordinated to the Second Operational Group. The commander of the Second Operational Group was Lieutenant General Pavle Strugar.39 The Second Operational Group headquarters was located at Trebinje (Bosnia and Herzegovina). With regards to the strength of the JNA forces that occupied the District of Dubrovnik, estimates range from 7,500 to 20,000 men. ${ }^{40}$ As soon as the JNA fired the initial artillery rounds at Konavle, the Montenegrin Ministry of Interior issued a secret order for the mobilization of the Special Police Unit that would assist the JNA in "carrying out combat operations in the conflict of war on the border between the Republic of Montenegro and the Republic of Croatia." 41 The then Montenegrin Minister of Interior, the late Pavle Bulatovic, signed the order. This unit was equipped with the necessary infantry weapons and medical provisions and put under the direct command of the assistant minister of the public security service, whose duty was to coordinate actions with "the operative command at the Dubrovnik theatre of war." 42

While the JNA forces and the reservists from Montenegro were slowly advancing towards Dubrovnik on October 4, 1991, the government of Serbia was in session. The the fighting in the Dubrovnik region was discussed as was the manner in which the government of Serbia should position itself with regards to those developments. The result of the debate was a letter issued by the Serbian government on October 5, 1991, and sent to the government of Croatia. The contents of the letter, signed by the Serbian Prime Minister at the time, Dragutin Zelenovic, indicated Belgrade officially distancing itself from the Dubrovnik campaign, but it also accused the Croatian government of provoking bloodshed. Claiming Dubrovnik as part of Serbian, as well as Croatian heritage, the government in Belgrade blamed its counterparts in Zagreb for sending "paramilitary units, Black Legions, and numerous foreign mercenaries," into the city and then "launching attacks on settlements in Herzegovina and Boka Kotorska." 43 The Serbian government characterized this alleged military deployment as "a totally uncivilized, inhuman, and undignified 
act," and expressed its firm belief that "all the members of the Yugoslav Army and units of the Territorial Defense will make an efforts in protect this historical town." 44

The rhetoric of this letter served many purposes. First, it blamed the Croatian authorities for provoking the conflict, but it also absolved JNA units of any responsibility for destruction that might occur in Dubrovnik. The alleged installment of "paramilitary units, Black Legions, and numerous foreign mercenaries" portrayed Dubrovnik as a legitimate military target and characterized the Croatian power structure as insensitive to the potential suffering of its people. 45 Second, it tried to demonstrate to the international community the peaceful intentions of the Serbian leadership despite facing Croatian politicians who were bent on war "at all costs." Third, the letter was aimed at portraying the government of Serbia only as an interested third party that had nothing to do with the events on the ground. Because it had been "acquainted with the danger to the civilian population and the city of Dubrovnik," the government in Belgrade could not, it was claimed, be held responsible for the outcome of the whole affair. ${ }^{46}$ In time, such distancing would lead to characterization of the Dubrovnik campaign as entirely Montenegrin operation.

The leadership of Montenegro immediately followed this cue and convened a joint extraordinary session of its parliament and its government on October 7, 1991. The discussion was focused on the issue of negotiating the future status of the Prevlaka Peninsula with the Croats and was based on an earlier proposal to rectify the border so that Prevlaka could become Montenegrin. ${ }^{47}$ A communiqué issued on October 8, 1991, stated that "Montenegro is not at war with the Republic of Croatia, nor has it any pretensions toward its territory." 48 The Montenegrin leadership further stated that reservists from Montenegro were members of the Yugoslav Army, and that the JNA "was the only instance responsible for their deployment." 49 It should not be forgotten that those lines were written while the Montenegrin reservists, its police force, and various paramilitary units under the overall command of the JNA were advancing through Konavle towards Dubrovnik. The self-confessed author of this communiqué, the former Foreign Minister of Montenegro, Nikola Samardzic, acknowledged recently that its content "was in contradiction with the actual state of affairs because war was being waged on Dubrovnik and a march further on towards Karlobag was being planned." 50 The Speaker of the Croatian Parliament responded on October 15, 1991, with a letter to the President of the Montenegrin 
Assembly, Risto Vukcevic, agreeing to meet with the representatives of Montenegro and continue the dialogue with Podgorica, in hope that peace and good neighborly relations could be re-established, but he also emphasized that "the atmosphere for discussion and dialogue would have been more favorable had your initiative appeared before the aggression on the Republic of Croatia from the territory of Montenegro." 51 The planned meeting never happened, and Nikola Samardzic asserted that it was Milosevic who dismissed the Montenegrin initiative. ${ }^{52}$

The political game played by Podgorica at the time was apparent in an interview that the Montenegrin Prime Minister Djukanovic gave to Pobjeda a few days before this extraordinary joint session. Despite the peace-oriented rhetoric in the official communiqué, in the interview the prime minister argued passionately in favor of war as the only solution for the current conflict on the border with Croatia because "partners in this dialogue on the Croatian side are Ustashas, cynics, crazed and blood thirsty criminals - in a word - mercenaries whose mission is to destroy the Yugoslav state." 53 He refused to acknowledge the fact that it was the JNA that launched an attack on Dubrovnik and not the other way around, and was firm in his belief that "Ustasha formations are threatening Montenegro and its citizens in the most direct way." 54

Contrary to the picture of doom presented by the Montenegrin politicians, army brass and the government-controlled media in Montenegro, the fact remains that the presence of the Croatian forces in the District of Dubrovnik in September 1991 was almost non-existent. A small unit armed with light weapons were guarding the Imperial Fort on Mount Srdj that was built during the Napoleonic period. This platoon was stationed about one kilometer up Mount Srdj above the Old Town of Dubrovnik. There were no other regular Croatian army units present in the region. The resistance to the JNA's advance was insignificant. Croatian President Stjepan Mesic remarked that "because of geopolitics it was impossible to organize a serious defense of Dubrovnik. Croatia didn't have forces able to stop the Yugoslav Armada." 55 Numerically small, poorly armed, and hastily formed units of "home guard" composed of men from the Croatian police and former members of Croatian descent who had deserted the JNA were no match for the armor of the JNA. The form of their resistance was such that there was no frontline distinction between the JNA and Croatian forces - only the edge of the area up to which the JNA had advanced at any given point in time. As Petar Poljanic, the former Mayor of Dubrovnik, stated during his testimony at the trial of Slobodan Milosevic, the Montenegrin media, its politicians, and high 
ranking JNA officers made a concerted effort at misrepresenting the military situation on the ground and exaggerated the "threat" of an attack on Montenegro by "30,000 armed Ustashas and 7000 terrorists, including Kurdish mercenaries. We had no mercenaries in our army. There was one foreigner, a Dutchman, who was married to a lady from Dubrovnik and who was there during the war. He volunteered to join the Croatian army." 56 A similar account was given by the former Montenegrin Foreign Minister, Nikola Samardzic, during his testimony at the trial of Slobodan Milosevic. Speaking about the October 1, 1991 extraordinary session of the government of Montenegro, Samardzic elaborated on the issues discussed.

I was quite shocked, but what was said was that Croatia had started to attack Montenegro, and that 30,000 Ustashas were ready to advance upon Montenegro and to take control of Boka, and that it was up to us to defend ourselves. That's what President Bulatovic said and this was borne out by General Strugar... This was commonly thought in the government and by the people. Many people believed that we had been attacked because there was enormous propaganda along those lines favoring war. 57

The immediate reason for the absence of any significant Croatian military presence in the region could be attributed to the fact that the Croatian authorities' assessment of the threat to this district was inaccurate. Certainly, the proportion of Serbs in this area was relatively low. Furthermore, the military authorities in Belgrade had affirmed that there were no plans to attack Dubrovnik. In addition, the District of Dubrovnik (apart from the Prevlaka Peninsula) had long before been largely demilitarized. The last regular army unit of any significance located in the District of Dubrovnik was moved to Bosnia and Herzegovina in 1968, and the territorial defense armament was transferred in 1972 to Duzi and Grab, also in Bosnia and Herzegovina.

At that time, the members of the European Commission Monitoring Mission (ECMM) arranged for representatives of the JNA forces and the city of Dubrovnik to meet in order to negotiate a cease-fire that would enable the necessary repairs to public utilities system and also facilitate prisoner exchanges. These negotiations and cease-fire arrangements had no real effect upon the advance of the JNA tow ard the city of Dubrovnik.

It is interesting to note that the JNA forces entered Croatia from the northwest at the beginning of October 1991. Even though the JNA experienced negligible resistance, its troops did not follow the same 
timetable as those JNA forces advancing from the southeast. The troops marching into Croatia from the northwest did not occupy their final positions around the city of Dubrovnik until approximately November 24, 1991. For almost a month these JNA troops halted their advance even though their comrades-in-arms coming from the southeast had brought their gun positions to the very edge of the city and a Yugoslav federal flag was hoisted on Zarkovica promontory on October 26, 1991.58

There may have been several reasons for this pause. First, from the beginning of October 1991, JNA forces had gained control of several strategically important locations on the border of Croatia and BosniaHerzegovina. This, in turn, effectively blocked access to Dubrovnik by land from the northwest. By sea, the city was blockaded by the Yugoslav navy. Considering these factors, it would appear that the JNA was in no hurry to reach the city gates from the northwest. The international significance of the Dubrovnik region might have been yet another factor contributing to a relatively slow advance of the JNA. Furthermore, the international community had put in place proposals that would limit the scope of the JNA's territorial expansion in the region. The Kouchner Plan, announced on November 19, 1991, called for JNA forces advancing from the northwest to stop at the village of Mokosica. These troop movements were to be monitored by representatives of the ECMM. The Kouchner Plan was followed by the Geneva Agreement of November 23, 1991, which also aimed at halting further troop advance into the Croatian coastal region. However, both of these agreements were violated as soon as they became effective.

The Imperial Fort on Mount Srdj above the city and the telecommunications tower next to it, as well as Zarkovica hill and the Ploce district (in the southeast of the city) were shelled on October 1, 1991, and again the following day. On October 3, the JNA shelled the Hotel Belvedere (in which there was a Croatian military post), and its aircraft dropped bombs in the sea near the Hotel Argentina. ${ }^{59}$ The Old Town was hit with 120-millimeter mortar fire and 82-millimeter rockets for the first time on October 23, 1991. The front sections of the Small Port in the southeast of the Old Town and the houses along the Stradun were hit by these projectiles, as were the St. John Fort and St. Peter's Bastion, which were being used as shelters. Among notable monuments hit were the Sponza Palace, the Jesuit Church, the Franciscan Bell Tower, and the Town Clock Tower. A home for the elderly south of the St. Claire Monastery and the city wall behind it were also hit by mortar fire. The location of these impacts was such that UNESCO observers concluded 
that the bombardment had come almost entirely from the southeast. Two days later, the JNA representatives presented an ultimatum to the Dubrovnik crisis committee and the ECMM representatives. The JNA demanded the disarmament of the city and the immediate departure of all Croatian military forces and "foreign mercenaries," as well as the removal of the public officials who had been elected during the previous free elections. ${ }^{60}$

The renewed shelling of the city on October 30,1991, resulted in six civilian casualties, while mortar fired on the hotel complex at Babin Kuk, on November 2, 1991, wounded several refugees housed there temporarily. Even though the JNA forces either had or ought to have had knowledge of the presence of thousands of refugees in these hotels, it would seem that the hotels in the New Town of Dubrovnik were deliberately targeted during the fall of 1991. Over the next couple of days, the Old Town was subjected to small arms and sniper fire, killing one civilian on the Stradun (Promenade in the Old Town). On November 7, a new ultimatum was announced on local radio, demanding that all Croatian forces surrender by noon. The following day, JNA commander Vice Admiral Jokic announced that the Croatian forces had rejected the ultimatum and that he would spare only the Old Town. On November 9, the Imperial Fort, Gruz, and Lapad were bombarded. The following day, the Imperial Fort was hit again, as were the Hotel Belvedere, the Excelsior Hotel, the Hotel Argentina and the Old Town. Naval vessels participated in this bombardment. The bombardment culminated in November in the systematic destruction, by wire-guided missiles, of every yacht in the harbor of the old city. ${ }^{61}$

According to a report by the ECMM, the selection of JNA targets on December 6 changed somewhat. The heavy shelling was directed towards the northwestern part of the Old Town. The Franciscan Convent, the buildings near the Stradun and buildings in the area southwest of the Stradun received heavy mortar fire. This bombardment not only struck the Old Town but also burned down the Inter-University Center along with its library of 20,000 volumes. During the Battle of Dubrovnik, 82 to 88 civilians were killed. The circumstances surrounding some of these deaths appear to be particularly disturbing. The deaths of firemen at the Libertas Hotel in the New Town of Dubrovnik on December 6, 1991, while they were fighting a fire appear to have been the result of a specific target by JNA forces. This is confirmed by the recording of a JNA radio transmission, which gave the order to direct mortar fire on the firemen. ${ }^{62}$ 
The invasion of the District of Dubrovnik by the JNA resulted in a large number of its residents seeking refuge within the confines of the city walls. These refugees numbered approximately 15,000, and most of them took shelter in the numerous hotels in the New Town (west of the Old Town). Approximately 7,000 refugees were evacuated by sea in October 1991. These evacuations became more difficult as the siege progressed, but negotiations with the JNA carried out by international organizations, such as the ICRC and UNICEF, with the assistance of Croatian humanitarian organizations and the local crisis committee, ensured that a further 9,000 persons (mainly pregnant woman, mothers with small children, the elderly and the sick), were able to leave by sea. The available evidence suggests that (even more so than in Konavle) the minuscule resistance to the southeastward advance of the JNA forces and the paucity of any valid military objectives in Primorje were such that many of the civilian injuries and casualties (which were significantly higher in Primorje than in Konavle) and much of the destruction of civilian property during this advance was not militarily necessary. It has been estimated that in the region of Dubrovnik, including the Old Town, 11,425 buildings were damaged (some more than others) by artillery fire and bombardment. As a result of the district's electrical grid being bombed by JNA forces, electricity and water to the city were lost on October 1, 1991. Except for those few people who had generators, the citizens of Dubrovnik lived without electricity until the end of December 1991.63

The JNA reservists not only forced people from their houses, but also engaged in massive looting, pillaging, and the destruction of private and historical property. It is hard to imagine how the looting and desecration of the Franciscan Monastery of St. Jerome in Slano or the destruction of parts of the old Arboretum of Trsteno can be anything but two glaring examples of destructive acts which were not militarily necessary. ${ }^{64}$ Heavy looting occurred in Kupari, where the hotel complex Vrtovi Sunca was virtually cleaned out of all its furniture and equipment, pieces of which were later either sold on the black market in Montenegro or given as "gifts" to various state-run institutions and organizations in Podgorica. In late October 1991 the author of this article personally witnessed the forceful presentation of one such "gift" from Kupari to the Director of the Clinical Center "Vukasin Markovic" in Podgorica. Six heavily armed reservists came to the main hospital entrance, unloaded three leather sofas and two leather armchairs, and while proudly displaying their submachine guns, knives, and other kind of "peace-making" equipment, literally scared the hospital director into accepting the stolen property as 
their generous "donation" for his office. Even though there were numerous individual soldiers and paramilitaries involved in looting and pillaging, it has been alleged that the spoils of war were collected in an organized fashion by the army. The former Foreign Minister of Montenegro, Nikola Samardzic, described these activities as robbery that was made to look like damage incurred during fighting.

They would take out valuables from houses, such as television sets, household appliances, etc. and then throw a hand-held rocket or something to destroy the house completely and destroy all the traces of looting. Make it look like damage incurred in the war." 65

One of the lesser known, but nonetheless disturbing case of wellorganized looting occurred in Cavtat shortly after the JNA overtook the town. According to reports by Pobjeda, on October 16, 1991 at 11:00 a.m. and "after learning that the Ustasha formations left the town, the Special Forces unit of the JNA, followed by infantry and motorized JNA units, entered Cavtat. This action was completed without a single bullet being fired." 66 What this report failed to mention was that after the JNA soldiers and reservists entered Cavtat they were ordered by one of their commanding officers to enter the Vlaho Bukovac Memorial Museum. Every single work of art displayed and stored in this museum was first neatly packed and then loaded up on army tracks to be taken to Montenegro as "spoils of war." After the information about this robbery reached European capitals in late 1992, a special committee was formed in London with the aim of pressuring the Montenegrin government into returning those works of art back to Cavtat. This committee, among others, included Nikola Patrovic, the descendant of the last Montenegrin king, Francisca von Habsburg, and Franz Muheim, the former Swiss Ambassador to the Great Britain. ${ }^{67}$

In spite of its advantages in manpower and equipment the JNA did not succeed in forcing the surrender of Dubrovnik. Considering the strength and capabilities of the JNA at the time, the question remains why its forces did not take the city. It would seem reasonable to assume that events in The Hague and in Belgrade overtook the ambitions of the Serbian and Montenegrin expansionists, and in May 1992, with the truce in Croatia already five months old, the Croats reached an agreement with the JNA. Its forces lifted the siege and withdrew from the area. 


\section{DREAMS OF CONQUEST AND REALITY OF \\ RECONCIL I A T ION}

As the negotiations concerning the lifting of the siege were approaching their final phase, it was clear that this campaign had been a military fiasco for the JNA. It also turned into a public relations nightmare for the political leaderships in Podgorica and Belgrade. A growing number of Montenegrins questioned the motives behind the campaign. Judging by the way the Dubrovnik campaign was covered in the Serbian press, some speculated about the true intentions of the attack on Dubrovnik. Dragan Veselinov, professor at the Faculty of Political Science in Belgrade, argued in 1991 that the JNA had found itself in an awkward position and without an exit strategy because it neither dared to openly rule Dubrovnik, "nor use it as a trump card against Milosevic in the negotiations. Milosevic might even curse the day Dubrovnik was attacked, since many will attribute it only to him and not to his generals." $68 \mathrm{He}$ criticized the army for poor decision-making skills and questioned its devotion to "protecting the Serbs in Croatia." 69

By questioning the rationale behind the campaign, Veselinov alleged a high level of disunity and a lack of coordination between the political leaderships in Podgorica and Belgrade and the JNA. While problematic on many levels, Veselinov's assessment of the situation framed one of the main points of contention with regards to the siege of Dubrovnik: was the Dubrovnik campaign planned and executed without the approval of Slobodan Milosevic? His comments squarely placed the blame on the JNA generals and not on Milosevic. While one could agree with Veselinov that Milosevic might not have been involved in the operational aspects of the Dubrovnik campaign, proving that "his generals" dared to besiege the city without his tacit approval would be a daunting task. Veselinov's statement served yet another purpose: to minimize the negative impact of the Dubrovnik campaign on Serbian political structures. This, in turn, was a deception of both the general public in Serbia and Montenegro, and the international community. Twelve years later, it became clear that the actions of the JNA around Dubrovnik were not the case of a group of disobedient generals going astray, but part of the broader political strategy of expansionist nationalism employed by the Montenegrin leadership.

While the onslaught on Dubrovnik was underway and the international community was strongly objecting to its aim and scope, the military brass and the politicians in Montenegro acted on different fronts 
to remedy the situation. They tried to justify their actions to the Montenegrin citizens by claiming that this military campaign, even though it entailed crossing into Croatian territory, was defensive in nature, and in so doing further inflamed the nationalist sentiments among the population. Bozidar Babic, the Montenegrin Defense Minister at the time ,talked about patriotism and the sacred duty of every Montenegrin to defend Yugoslavia. He wondered if one "really has to ask why step outside the Montenegrin borders? Should we leave the JNA soldiers and all those who wish to live together at the mercy of the Ustasha beasts? The borders to be defended are wherever a single soldier of ours, a soldier of the JNA, is attacked."70 Moreover, Branko Kostic, the interim President of the SFRY Presidency, had warned earlier that Montenegro would defend itself, and "it would do that not only within its own borders."71 After the lifting of the siege in May 1992, Svetozar Marovic justified the involvement of Montenegrin reservists and police forces in the aggression on Dubrovnik by saying that it was not possible to secure peace in any other way, and that Montenegro was "unable to influence the beginning of the war. It was imposed by Croatian egoism."72

On the one hand, the politicians in Podgorica and Belgrade also had broader concerns about the reaction of the international community to the manner in which the former Yugoslavia dissolved. Until the attack on Dubrovnik, Serbia was the sole proprietor of the title "Defender of Yugoslavia" while Montenegro for the most part stood aside. Montenegro was involved in the initial phases of the war in Croatia only to the extent that allowed its soldiers to be recruited to the JNA. ${ }^{73}$ Its enthusiastic participation in the onslaught on Dubrovnik raised questions about personal gains for the Montenegrin politicians. ${ }^{74}$ On the other hand, the "newly elected" Montenegrin leadership needed to strengthen its grip on power and it chose to accomplish that by demonstrating its loyalty to its mentor in Belgrade. The prospects of territorial expansion indeed found fertile ground in Montenegro. Novak Kilibarda, then leader of the proMilosevic People's Party, and many other supporters of Greater Serbian nationalism in Montenegro were hoping that the military incursion into Croatia would realize their dreams of "reclaiming" a long lost territory: the so-called Serbian Republic of Dubrovnik. In late summer 1991, Novak Kilibarda was a passionate advocate of attacking Dubrovnik because "in order to save those Serbs who would be slaughtered by Ustashas, we need to hit from the south, from underneath, and force Croatia to fight us there!" 75 With the passage of time, however, attitudes changed and, in the summer of 2003, not without a healthy dose of cynicism, Kilibarda claimed 
that, at the time, he has been manipulated by the biased media reports: "I was confused after hearing about 30,000 Ustashas on the move! TV Belgrade and Montenegrin TV provided the news and I, like a child, was frightened... Imagine how others felt when even I, a university professor, fell for it."76 Some Montenegrin politicians, however, remained proud of their actions in 1991. On October 1996, the former President of Montenegro, Momir Bulatovic, reminded the general public that "the day after the first ecological state in the world was established, boys wearing JNA uniforms crossed the border of the Republic of Montenegro in order to legitimately defend the Socialist Federal Republic of Yugoslavia. We were the party that stood behind both of those actions."77 More recently, General Momcilo Perisic, the former Chief of the JNA General Staff and a person responsible for the initial shelling of the Bosnian city of Mostar, stated recently that it was Stjepan Mesic who "was shelling Dubrovnik and was responsible for the conflict in Mostar." Perisic further claimed that Mesic did this "so that he could later accuse Serbs of everything that happened."78

The politicians in Belgrade thought that the engagement of Montenegro in trying to achieve what were effectively Serbian war aims would have a positive effect on international public opinion and policy makers. Their intentions were twofold. First, to demonstrate that the war in Croatia and military activities of the Serb-controlled JNA throughout the former Yugoslavia in general were not guided by the selfish interests of Serbia but were aimed at protecting the interests of all citizens of the former Yugoslavia and at saving the federal state. Once the negative consequences of the "War for Peace" became clear, the political leadership in Belgrade tried to distance itself from it, claiming that the Dubrovnik Campaign had nothing to do with Serbia but had been solely inspired by Montenegro and its desire for territorial expansion. In the face of the overwhelming evidence to the contrary, many politicians and intellectuals in Serbia still adhere to such a view. Second, to distract the world's attention from the events that took place around the city of Vukovar and gain the time needed to re-design a message to the international community about Serbia and Montenegro fighting hand-in-hand against the so-called retrograde political forces in the region. It is worth remembering that at the outset of the Yugoslav crisis some segments of the international community (Russia, for example) had shown sympathy for Serbian war aims.

The overall strategy was, and remains to this day, to minimize the importance of the Dubrovnik campaign, distort analyses of its nature, and dispute reports about large-scale destruction of property and civilian 
casualties. ${ }^{79}$ In the early 1990s, such efforts varied from complete denial of the JNA's involvement to nationalistic rationalizations of the attack. JNA spokesman Yugoslav Army Colonel Milan Gvero, the man who earlier masterminded the grotesque media tour of "liberated" Vukovar, dismissed reports of Dubrovnik's destruction and claimed that the Croats were setting fire to piles of burning car tires. In the face of the overwhelming evidence to the contrary, Gvero claimed that "Not a single speck of dust has fallen on Dubrovnik." 80 On the other side of the spectrum, a prominent Serbian historian and member of the Serbian Academy of Arts and Sciences, the late professor Radovan Samardzic, showed little sympathy for Dubrovnik. For him, it was "a city of hotel owners who prostitute themselves and a place where American grannies, British homosexuals, stupid Frenchmen, and German secretaries come for a holiday. Anyhow, southeastern Europe is almost a colony of German secretaries." 81

At present, the assessments and justifications of the Dubrovnik campaign differ somewhat from those expressed in 1991-2. During the last couple of years, and despite a number of unresolved issues, political and diplomatic relations between Croatia and Montenegro have seemingly improved. The earlier contested claims over the Prevlaka Peninsula, which seem to have been the immediate reason for the conflict, now appear settled. Croatia recently gained complete control over the area, the border crossing with Montenegro at Prevlaka Peninsula has reopened and Croat authorities are planning to develop the area as a tourist resort. There is also a tendency among the Montenegrin political and military elites to view this relationship as normalized, thus implying that past conflicts are now over and earlier contested issues are settled. Montenegrin politicians argue that it is not necessary to revisit this episode because reopening it would only prove detrimental to the ongoing process of reconciliation. It would seem that the Croatian authorities feel comfortable with such arrangements especially since they regained the territory initially lost during the conflict in the Dubrovnik region and, more importantly, they now occupy the moral high ground vis-à-vis Montenegro. ${ }^{82}$

Revisiting the issue of the 1991 siege of Dubrovnik is, therefore, crucial for a number of reasons. Above all, it is important in the context of the much-needed process of a multi-leveled reconciliation in the region: within Montenegro, and between Montenegrins and their Croat neighbors.

From the outset of the Yugoslav crisis, Montenegro was a divided society. In the early 1990s the lines of division within Montenegro were drawn not only by the political views and party affiliation of its citizens 
but also by their attitude tow ards the Dubrovnik campaign. A numerically small but vocal minority that rallied around the Citizens' Forum of Montenegro and the magazines Monitor and Liberal opposed the campaign. The structures of power in Montenegro treated these Montenegrin refusniki as not only traitors and enemies of the state, but also as individuals who were not worthy of calling themselves Montenegrin. Confronting the mistakes from the past and clearly identifying political and military responsibilities for this disastrous campaign should therefore ease the tensions within Montenegro and lift the "burden of guilt" from all those who in 1991 advocated restraint. ${ }^{83}$ This is long and arduous process and the political elite in Montenegro is not yet willing to confront these demons from the past.

The politicians in Podgorica and Belgrade repeatedly claim that 95 per cent of Montenegrins in some way participated in this campaign. They play this numbers game for selfish reasons. The Serbian political elite still adheres to the view of the Dubrovnik campaign as an adventure induced and organized by the Montenegrin political elite. The leadership in Podgorica resorts to generalizations in order to avoid answering questions about individual responsibility (political or otherwise). Both are hoping that, once the trials of the army brass in The Hague are over and sentences passed, the issue of individual responsibility for the political decisions would somehow evaporate into thin air.

The argument that the masses can be manipulated if they are susceptible to manipulation is indeed to a certain extent valid. Belgradebased sociologist, Zagorka Pesic-Golubovic, is a forceful advocate of such a view. Moreover, the former Mayor of Belgrade, Bogdan Bogdanovic, went a step further and suggested that criminal intent with regards to the treatment of "others" was imprinted onto the Serbian psyche long before the actual conflict in the former Yugoslavia started. ${ }^{84}$ While not disputing the fact that a significant number of Montenegrins and Serbs gladly joined the Dubrovnik campaign, I would argue that instead of debating the issue of collective responsibility and implying the existence of violence as a character trait (being violent), it is prudent to first analyze the nature of the expansionist nationalism among the South Slavs and elaborate on the internal dynamics of the process of becoming violent. 85

The attempts of the political elites to evenly distribute the responsibility for the Dubrovnik campaign seem to be a self-serving exercise. Such rhetoric is aimed at de-personalizing guilt and unjustly spreading it among the entire population of Montenegro, while leaving the wrong impression of Montenegrins as spellbound by the notion of 
"collective guilt." This impression is, however, imposed from above and has little to do either with the way the Montenegrin general public feels about the siege of Dubrovnik or with the widely discussed issue of reconciliation. It is worth repeating that the political elites who advocate such depersonalization are the same elites who were in power in Montenegro during the Dubrovnik campaign. It is, thus, understandable why the current structures of power in Podgorica would like to avoid facing the past and dealing with its consequences.

Uncertainty about the reactions of the international community with regard to the role Montenegrin and Serbian elites played in the breakup of the former Yugoslavia in general and the Dubrovnik campaign in particular might have been one of the reasons behind a recent series of public apologies issued by the current Montenegrin leadership and the president of Serbia and Montenegro, Svetozar Marovic. 86 The first to apologize to the Croats was Montenegrin Prime Minister Djukanovic. During his June 2000 meeting in Cavtat with Croatian President Stjepan Mesic, the Montenegrin prime minister expressed "regret for all the pain and material damage inflicted by any member of the Montenegrin people." 87

Reactions in Serbia and Montenegro to Djukanovic's apology varied. The former leader of the Montenegrin Socialist Democratic Party, Zarko Rakcevic, saw it as a "positive and wise step," but reminded Djukanovic that he should also apologize to "citizens of Montenegro who were harassed because they opposed the pointless war with Croatia." 88 Leaders of the Serbian opposition parties reacted differently to Djukanovic's statement. Predrag Simic, advisor to Vuk Draskovic, President of the Serb Renewal Movement, interpreted it as the step of a politician who wants to "send the past into history and to create a new future for these two countries." 89 Democratic Party of Serbia President Vojislav Kostunica said that Djukanovic had "washed his hands of his participation in the war and tried to present himself as a completely different person, a completely Western man." 90 Kostunica also reminded the general public that Djukanovic "had created the Montenegrin and Yugoslav policy at the time and now he was trying to pretend it had been someone else." 91

Three years later, in 2003, another Montenegrin "hawk" from the time of the War for Peace underwent a political catharsis similar to that of Djukanovic. In a rather theatrical manner, the current President of the newly formed state of Serbia and Montenegro, Svetozar Marovic, apologized to Croats and Bosnians for "all evil acts and wrongdoings" 
committed against them by the citizens of Serbia and Montenegro. ${ }^{92}$ Marovic then proceeded to apologize to those Montenegrins whom he, together with his party colleagues, Milo Djukanovic and Momir Bulatovic, persecuted to the full extent of the law twelve years ago. ${ }^{93}$

While reports of these apologies and various assessments of their genuineness, or the lack thereof, filled the front pages of newspapers, an effort to destroy the evidence of past political actions and war mongering rhetoric seem to have been under way in Montenegro. The more radical example of the efforts to bury mistakes from the past is the vanishing of almost all the archival video material related to the Dubrovnik campaign and the role Montenegro played in this process from the archives of the Montenegrin State Television. Furthermore, numerous copies of the Montenegrin daily Pobjeda from 1991 have mysteriously disappeared from the shelves of the City Library in Podgorica. ${ }^{94}$

The delay in completing the judicial proceedings in The Hague against former JNA officers accused of a breach of the Geneva Convention's regulations and rules of war during this campaign has not helped the process of reconciliation at the local level. The longer the proceedings last the more the Montenegrin political elite behaves as a protected witness even though its responsibility for the Dubrovnik campaign is apparent. This, however, might also be a sign of Brussels' pragmatic politics, since the importance of the Montenegrin political elite as a permanent witness on the witness-stand on behalf of the international community in the process of "proving" that the Balkan slaughterhouse was not an interethnic civil war but Greater Serbian aggression on the sovereign states of Croatia and Bosnia should not be underestimated.

The "War for Peace" has turned out to be one of the most shameful episodes in recent Montenegrin history, and it has left a dark spot on the memory maps of many Montenegrins. As Nikola Samardzic pointed out, the onslaught on Dubrovnik "was an unjust war against Croatia, and a war in which Montenegro disgraced itself by putting itself in the service of the Yugoslav army and Slobodan Milosevic." 95

With the benefit of hindsight it could be said that the ideological motivation behind this campaign, its military and political dynamics, and its obvious catastrophic results clearly prove that the operation's true aims were twofold: to destroy as much as possible of the region on the Croatian coast, to pillage its towns and villages, and to implicate Montenegro and its citizens in a malevolent military campaign of territorial expansion designed by Greater Serbian nationalists in Serbia and Montenegro. Not unlike other nationalisms, Greater Serbian 
nationalism needed to spill the blood of "others" so that all bridges connecting us with our neighbors would be burned down. It also needed to spill the blood of many Montenegrins as the final proof of a long-standing and long-lasting Serbian-Montenegrin unity. A few hundred citizens of Montenegro and Croatia paid the ultimate price for this political and military adventure. The graves of those Montenegrin citizens who gave their lives in this campaign are all but forgotten. Memories of those Montenegrins who died "at Dubrovnik" are no longer revered because of the terrible burden of guilt overshadowing the entire nation. They fell from grace even though they were the victims and not the creators of this danse macabre.

\section{ENDNOTES}

1 The slogan "The War for Peace" was coined sometime in 1991 by the current President of Serbia and Montenegro, Svetozar Marovic, who at the time was the vice president of the ruling Democratic Party of Socialists (DPS) in Montenegro.

2 James Gow, Triumph of the Lack of Will: International Diplomacy and the Yugoslav War (New York: Columbia University Press, 1997), pp. 58-60.

3 Such views have been voiced recently by the prominent Montenegrin movie director Zdravko Velimirovic.

The IPG OBALA is the Podgorica-based TV-Video Production organization. The documentary "The War for Peace" in Montenegro, Serbia, and Croatia was screened in late April 2004. This documentary was also shown as part of the official program of the 9th Annual World Convention of the Association for the Study of Nationalities (ASN), entitled "Nation, Identity, and Conflict," Columbia University, New York, April 15-17, 2004.

5 An unknown Montenegrin army reservist on the "frontline" in Konavle, in the late fall 1991. Personal communication.

6 "Chronology of Dubrovnik," at http:/ /www.dubrovnik-online.com. Also see Ferdo Sisic, Pregled Povijesti Hrvatskoga Naroda (Zagreb: Matica Hrvatska, 1962), pp. 80-84, as well as Miljenko Foretic, “The Ragusan (Dubrovnik) Republic and the War for the Spanish Legacy 1701-1714," in Anali Zavoda za Povijesnu Znanost HAZU u 
Dubrovniku, No. 31, Vol. 31, Dubrovnik, 1993, pp. 71-117, and Nenad Vekaric, "The Population of the Dubrovnik Republic in the 15th, 16th, and 17th Century," in Anali Zavoda za Povijesnu Znanost HAZU u Dubrovniku, No. 29, Vol. 29, Dubrovnik, 1991, pp. 7-21.

Adam S. Eterovich, Croatia in the New World: Columbus, the Republic of Ragusa (Dubrovnik) and Saint Vlaho (Saint Blaise) - Patron Saint of Dubrovnik (Dubrovnik: Ragusan Press, 1992), pp. 32-8.

8 "Chronology of Dubrovnik," at http://www.dubrovnik-online.com.

9 Josip Lucic, "Chronology of Dubrovnik," in Place and Destiny, The Bridge/Most/Pons: A Journal of Croatian Literature, Proceedings from 59th P.E.N. World Congress, Dubrovnik, April 15-25, 1993, pp. 10868.

10 Igor Zidic, “The Painter's Arcady or a City in a Golden Frame," Ibid, p. 72.

11 On the role Dubrovnik played in the sixteenth and seventeenth centuries Mediterranean political theater, see Fernand Braudel, The Mediterranean and the Mediterranean World in the Age of Philip II, Translated form the French by Siân Reynolds, vol. 1 (Berkeley and Los Angeles: University of California Press, 1995), pp. 125-33.

121991 Yugoslav Census.

13 On the notion of "unwanted other" and the nature of modern-day nationalism in the former SFRY see Srdja Pavlovic, "Understanding Balkan Nationalism: The Wrong People, in the Wrong Place, at the Wrong Time," Southeast European Politics On Line. Vol. 1. No. 2. December 2000. CEU, Budapest. Available at: http://www.seep.ceu.hu.

14 Borisav Jovic stated: "I said we should allow Slovenia to leave Yugoslavia and pull the JNA out. I proposed that the Federal Assembly should recognize Slovene secession, and agree to a division of assets with Slovenia, and a territorial delineation. There was no discussion of my proposal because everybody was absolutely confused and stunned. They thought it inconceivable that any Presidency member could talk about the disintegration of Yugoslavia." Laura Silber and Allan Little, The Death of Yugoslavia, revised edition (London: Penguin Books and BBC Books, 1996), p. 161. For the Serbian nationalist point of view on this issue, see Dr. Milan Tepavac, "On Proceedings Against Admiral Miodrag Jokic Before So-Called Hague Tribunal,» August 31, 2003. Available at: 
Balkannews, http://www.mailarchive.com/balkannews@yahoogroups.com/msg00699.html General Veljko Kadijevic, Moje Vidjenje Raspada: Vojska bez Drzave (Belgrade: Politika, 1993), p. 131.

16 "Final Report of the United Nations Commission of Experts established pursuant to Security Council Resolution 780 (1992)," Annex XI .A The Battle of Dubrovnik and the Law of Armed Conflict, United Nations - Security Council, S/1994/674/Add.2, (Vol. V), December 28, 1994, pp. 13-14. For the comprehensive account of the role of the international community in the process of the dissolution of the SFRY also see J. Gow, Triumph of the Lack of Will.

17 R. Krsmanovic, "Pokrice za Dezerterstvo," Pobjeda, No. 9221, Podgorica, August 4, 1991, p. 8.

18 B. Novakovic and R. Perisic, "U Sjenci Stranackih Interesa," an interview with the Montenegrin Prime Minister Milo Djukanovic, Pobjeda, No. 9266, Podgorica, September 18, 1991, p. 7.

19 Ibid, p. 7.

$20 \quad$ Ibid, p. 7.

21 "The War for Peace, Part I," documentary film. Production: Independent Production Group Obala, Podgorica, 2003.

22 D. Draskovic, "Puske ili Kisobrani," Pobjeda, No. 9020, Podgorica, January 13, 1991, p. 3.

23 Svetozar Marovic, “Vlak Mira," Pobjeda, No. 9222, Podgorica, August 5, 1991, p. 5, and an interview with Svetozar Marovic in J. Stamatovic, "Dogovor Evropu Gradi,", Pobjeda, No. 9226, Podgorica, August 9, 1991, p. 5.

24 Svetozar Marovic, "Veze," Pobjeda, No. 9229, Podgorica, August 12, 1991, p. 5.

$25 \quad$ Ibid, p. 5.

26 "Razgovori Vranicki-Djukanovic," and "Razgovori DjukanovicMok," Pobjeda, No. 9253, Podgorica, September 5, 1991, p. 1 an p. 20.

$27 \quad$ Ibid, p. 20.

28 Srdja Pavlovic, “Makaze za Sjecanje," PCNEN, April 25, 2003. Available at: http://www.pcnen.cg.yu. Also see Marko Vesovic, "Svetovo Izvinjenje," Monitor, No. 683, Podgorica, November 21, 2003.

29 “Mobilizacija Dvije Ratne Jedinice," Pobjeda, No. 9264, Podgorica, September 16, 1991, p. 4. 
“Mobilizacija zbog Odbrane," Pobjeda, No. 9266, Podgorica, September 19, 1991, p. 5.

Pobjeda, No.9272, Podgorica, September 24, 1991, p. 6.

32 Ibid, p. 6. HDZ is the abbreviation for the Croatian ruling party, Croatian Democratic Union.

33 M. Vico, “Oruzje Miruje," Pobjeda, No. 9270, Podgorica, September 22,1991, p. 5.

$34 \quad$ Ibid, p. 5.

35 M. Vico, “Rafali Upozorenja," Pobjeda, No. 9272, Podgorica, September 24, 1991, p. 1.

36 See Pobjeda, No. 9275, Podgorica, September 27, 1991, p. 1, and all subsequent 1991 issues.

37 A few days before the Dubrovnik campaign started, his helicopter was shot down and he was killed. The Montenegrin media blamed the Croatian "Ustashas" for his death.

38 Momcilo Popovic, "Bojovnici na Koljenima," Pobjeda, No. 9281, Podgorica, October 2, 1991, p. 1.

39 General Strugar, Vice Admiral Jokic, and Captain First Class Kovacevic have been indicted by the ICTY in The Hague and accused of violating the Laws or Customs of War. The court proceedings for General Strugar are currently under way, while Kovacevic is still at large. On August 27, 2003, Jokic pleaded guilty to murder, cruel treatment, attacks on civilians, devastation, unlawful attacks on civilian objects and destruction or willful damage to historic monuments and institutions related to religion. In exchange for his guilty plea, the prosecution reportedly agreed to drop the other three charges and to seek a sentence of nomore than 10 years imprisonment - although the judges do not have to follow the prosecutors' recommendation. See The International Criminal Tribunal for the Former Yugoslavia (ICTY), Indictments for Pavle Strugar, Miodrag Jokic, and Vladimir Kovacevic, Case No. IT-01-42. Also see "Serb Guilty of Dubrovnik Shelling," BBC News, August 27, 2003. Available at: http: / / news.bbc.co.uk/2/ hi / europe/3185537.stm.

40 The following units were under the General Strugar's command: 37 th Corps (Uzice); 2nd Corps (Podgorica/Titograd); 9th VPS (9 Naval Sector); 472th mtbr (Motorized Brigade, Trebinje); and 2nd Tactical 
Group. Vice-Admiral Jokic was in charge of the 472th mtbr (Motorized Brigade, Trebinje); 5th pmtbr (Partisan Motorized Brigade, Podgorica/Titograd); 16th GMO (Border Patrol Detachment, Boka); 107th OAG (Coastal Artillery Group) of 9th VPS; POAD (mobile coastal artillery) of 9th VPS, and the Territorial Defense Units from Herceg Novi, Kotor, Tivat, Budva, Bar, Mojkovac, Bijelo Polje and Trebinje. Annex XI.A The Battle of Dubrownik and the Law of Armed Conflict, United Nations - Security Council, S/1994 /674 / Add.2, (Vol. V), December 28, 1994, pp. 1516.

Secret Order signed by Pavle Bulatovic, October 2, 1991. Exhibit 338. Tab. 3. Marked: Secret. The Hague, ICTY, Testimony of the former Montenegrin Foreign Minister, Nikola Samardzic, during the trail of Slobodan Milosevic. Transcripts. Available at: http:/ / mitglied.lycos.de/desarea/

42 Ibid, Exhibit 338. Tab. 3.

43 Exhibit 338. Tab. 4. The Hague, ICTY, Testimony of the former Montenegrin Foreign Minister, Nikola Samardzic, during the trial of Slobodan Milosevic. Transcripts, p. 11202 (104/131). Available at: http://mitglied.lycos.de/desarea/.

44 Ibid, Exhibit 338. Tab. 4.

$45 \quad$ Ibid, Exhibit 338. Tab. 4.

46 Ibid, Exhibit 338. Tab. 4.

47 The letter sent to Zagreb effectively acknowledged Croatian independence and sovereignty but also indicated that Montenegro indeed had certain territorial aspirations: "Taking into consideration the decision of the Republic of Croatia to become a sovereign and independent state, the Assembly of the Republic of Montenegro considers that such a decision, apart from raising a series of legal and state issues, also changes the status of the border between the Republic of Montenegro and the Republic of Croatia, as it has been to the present. The existing border in the area of the Prevlaka peninsula is a hindrance to the establishment of a just and rational boundary in the coast waters and the continental shelf and therefore believes a minor correction necessary." Exhibit 338. Tab. 5. The Hague, ICTY, Testimony of the former Montenegrin Foreign Minister, Nikola Samardzic, during the trial of Slobodan Milosevic. 
Transcripts, p. $11207 \quad(109 / 131)$ Available at: http://mitglied.lycos.de/desarea/.

48 Exhibit 338. Tab. 5. The Hague, ICTY, Testimony of the former Montenegrin Foreign Minister, Nikola Samardzic, during the trial of Slobodan Milosevic. Transcripts, p. 11209 (111/131). Available at: http:/ / mitglied.lycos.de/desarea/. See also "Montenegro is not at War," Pobjeda, No. 9282, Podgorica, October 3, 1991, p. 1.

49 Ibid, Exhibit 338. Tab. 5.

$50 \quad$ "These documents that you read out just now were ones written by me personally. They were approved by President Bulatovic and by Prime Minister Djukanovic." Testimony of the former Montenegrin Foreign Minister, Nikola Samardzic, during the trial of Slobodan Milosevic. Transcripts, p. 11209 (111/131). Available at: http://mitglied.lycos.de/desarea/.

51 Ibid, Transcripts, p. 11211 (113/131). Available at: http://mitglied.lycos.de/desarea/.

52 Ibid, Transcripts, p. 11213 (115/131). Available at: http://mitglied.lycos.de/desarea/.

53 Milo Djukanovic, “Dobicemo Nametnuti Rat," Pobjeda, No. 9282, Podgorica, October 3, 1991, p. 4.

$54 \quad$ Ibid, p.4.

55 Interview with Stjepan Mesic. "The War for Peace Part I," Produced by Independent Production Group Obala, Podgorica, 2004.

56 Petar Poljanic's testimony at the trial of Slobodan Milosevic. Available at:

http://www.danas.org/programi/haaska/2002/12/2002121319094 1.asp. See also the testimony of Nikola Samardzic during the trial of Slobodan Milosevic. Transcripts, p. 11193. Available at: http://mitglied.lycos.de/desarea/.

57 Testimony of Nikola Samardzic. Ibidem. Transcripts, p. 11192. Available at: http://mitglied.lycos.de/desarea/.

58 Annex XI.A The Battle of Dubrovnik and the Law of Armed Conflict, United Nations - Security Council, S/1994/674/Add.2, (Vol. V), December 28, 1994, p. 19.

59 A poet from Belgrade, Milan Milisic, was the first civilian casualty in Dubrovnik. He was killed when his house was hit by artillery fire on October 5, 1991. See “The Interview with Painter Jelena 
Trpkovic," Radio Free Europe, August 5, 2000. Available at: http:/ /www.danas.org/programi/magazin/nocni/2000/08/20000 805073642.asp

Annex XI .A The Battle of Dubrovnik and the Law of Armed Conflict, United Nations - Security Council, S/1994/674/Add.2, (Vol. V), December 28, 1994, p. 24.

$61 \quad$ Ibid, pp. 25-6.

$62 \quad$ Ibid, p. 27.

63 "With respect to civilians who died as a result of hostilities, at least 82, (and possibly as many as 88), from the District of Dubrovnik were killed as a result of the JNA advance and occupation of the area from September 1991 until the end of December 1992. It is also clear that most (about 50) of these civilians died as a result of JNA action prior to the St. Nicholas Day bombardment on December 6, 1991. Thirteen civilians died as a result of the bombardment on that date, and this represented the greatest number of civilian deaths that was, or would be, sustained on a single day during the Battle of Dubrovnik. About 20 more civilians were killed over the next twelve-month period as a result of the hostilities." Annex XI .A The Battle of Dubrovnik and the Law of Armed Conflict, United Nations Security Council, S/1994 / 674 / Add.2, (Vol. V), December 28, 1994, p. 34 .

64 "Where is your TV? It is shipped to Niksic. Where are your cows? Shipped to Niksic. They robbed everything, like termites. That was a drunken army. Once in Trebinje, I saw three drunk generals and a battalion of completely drunk soldiers." Interview with Novak Kilibarda. "The War for Peace Part I," produced by Independent Production Group Obala, Podgorica, 2003.

65 Testimony of Nikola Samardzic at the trial of Slobodan Milosevic. Transcripts, p. 11197 (99/131). Available at: http:/ / mitglied.lycos.de/desarea/

66 “Jedinice JNA Usle u Cavtat," Pobjeda, No. 9295, Podgorica, October 16, 1991, p. 1.

67 Due to issues of safety and security, the commanding officer of the JNA reserves who monitored the emptying of the museum could only be mentioned here by his initials, M.Dj. The author of this article learned specific details about the looting in Cavtat and the activities of the Committee in London from the former Swiss Ambassador to Great Britain, Franz Muheim. Personal communication. 
Dragan Veselinov, "Dangerous Dreams," Vreme News Digest Agency, No. 7, November 11, 1991.

Ibid.

Srdja Pavlovic, “Dnevnik 'Rata za Mir' 1990 - 1992,” p. 49, unpublished.

$71 \quad$ Ibid, p. 50.

72 See Marko Vesovic, "Svetovo Izvinjenje," Monitor, No. 683, Podgorica, November 21, 2003.

73 The statements of Nikola Samardzic, the former Montenegrin Foreign Minister as a witness during the Milosevic trial at The Hague. ICTY, "Transcripts: Milosevic, Kosovo, Croatia and Bosnia-Herzegovina (IT-02-54)," The Hague, October 8, 2002. Available at: www.un.org / icty / transe54 / 021008IT.htm

74 Florian Bieber, "Montenegrin Politics Since the Disintegration of Yugoslavia." Available at:

http:/ / www.policy.hu/bieber/Publications/bieber.pdf, pp. 17-18. Archival footage of Novak Kilibarda, speaking in 1991. “The War for Peace Part I" documentary film. Produced by Obala Independent Production Group, Podgorica, 2003.

76 The interview with Novak Kilibarda in the three-part documentary "The War for Peace Part I," Produced by Obala Independent Production Group, Podgorica, 2003.

Srdja Pavlovic, “Dnevnik 'Rata za Mir' 1990-1992," p. 50, unpublished. "The international media, the Director-General of UNESCO (Federic Mayor), and Cyrus Vance (the UN negotiator for the Yugoslavian crisis) protested strongly about the bombardment of December 6, 1991. The ECMM in Zagreb also lodged a strong protest the same day. In response, the JNA promised "a full investigation of the incident" and asked Croatia to do the same. Later that day, a statement of regret and apparent intention to discipline those responsible was received from the JNA." Annex XI .A The Battle of Dubrovnik and the Law of Armed Conflict, United Nations - Security Council, S / 1994 / 674 / Add.2, (Vol. V), December 28, 1994, p.32.

80 Srdja Pavlovic, "Dnevnik," p.52.

$81 \quad$ Ibid, p. 47. 
“While many Croats remember Montenegro's instrumental role in the tragic siege of Dubrovnik, the government recognizes that Djukanovic is creating a more democratic and peaceful model for the FRY." NATO Parliamentary Assembly, Trip Reports, Economic Committee Sub-Committee on East-West Economic Co-operation and Convergence, Visit to Croatia, May 3-5, 2000.

83 "I saw the attack on Dubrovnik as a degradation of Montenegro and time has proven me right. Traditional Montenegro with all its moral values was forever shattered into pieces on the walls of the Old Town." Interview with Slavko Perovic, Leader of the Liberal Alliance of Montenegro, 1991. “The War for Peace Part I," produced by Independent Production Group Obala, Podgorica, 2003.

84 Branko Vojicic, "Marovicev Rat i Mir: Izvinite Sto Smo Vas Ubijali," Monitor, No. 683, Podgorica, November 21, 2003, p. 12.

85 Many Montenegrin soldiers and reservists who took part in the Dubrovnik campaign quickly realized that stories about numerically strong and well-armed Croatian army were false. "I want to stress that I haven't seen enemy soldiers anywhere in Konavle, but that could be because I was with the artillery. After we entered Konavle, the soldiers realized something was wrong. There were questions and complaints: "Where are we going?" "What are we doing?" I have to say that we never got any answers from our officers, who told us they didn't know either." Interview with a former JNA Captain. "The War for Peace Part I," Produced by Independent Production Group Obala, Podgorica 2003.

86 The Montenegrin media continuously speculate about new indictments with regard to the Dubrovnik campaign being prepared in The Hague.

87 Available at: Media Club.

http: / / www.mediaclub.cg.yu/eng/news / archive / 2000 / june / 26in dex.htm

88 “Vice President of Social Democratic Party, Partner in Montenegrin Ruling Coalition:

Djukanovic Should Also Apologize to Montenegrins Who Were Against War Adventure." Available at: Media Club. 
http://www.mediaclub.cg.yu/eng/news/archive/2000/june/26in dex.htm

89 “Different Reactions of Serb Opposition to Djukanovic's Apology: The Brave Step of a Politician Who Wants To Send Past Into History." Available at: Media Club. http://www.mediaclub.cg.yu/eng/news/archive/2000/june/26in dex.htm

$90 \quad$ Ibid.

91 Ibid.

92 Branko Vojicic, "Marovicev Rat i Mir: Izvinite Sto Smo Vas Ubijali," Monitor, No. 683, Podgorica, November 21, 2003, p. 12.

$93 \quad$ Ibid, p. 12.

94 Srdja Pavlovic, “Makaze za Sjecanje," PCNEN, April 25, 2003. Available at: http://.www.pcnen.cg.yu

95 Testimony of Nikola Samardzic at the trial of Slobodan Milosevic. Transcripts, p. 11191 (93-131). Available at:

http:/ / mitglied.lycos.de/desarea/ 